Part of Journal of Research of the National Bureau of Standards, Volume 30, May 1943

\title{
FUNCTION OF CARBON DIOXIDE IN PRODUCING EFFLO- RESCENCE ON PLASTER AND CEMENT PRODUCTS
}

\author{
By Dana L. Bishop
}

\section{ABSTRACT}

Hydrated magnesium sulfate was identified as the principal compound in efflorescence on white-coat plaster finish. This salt is not a constituent of the white-coat backing but is formed by reactions involving gypsum and magnesia in the plaster, carbon dioxide from the air, and water. The reaction to form magnesium sulfate cannot take place until after the $\mathrm{Ca}(\mathrm{OH})_{2}$ has been changed to $\mathrm{CaCO}_{3}$. Magnesium sulfate efflorescence may also be formed on cement products by the same reactions.

I. Introduction

II. Efflorescence on plaster

1. Chemical constituents of plaster and efflorescence $\ldots \ldots \ldots 2$

2. Formation of nesquehonite $\ldots \ldots \ldots 2$

3. Reaction of nesquehonite with gypsum

4. Effect of carbon dioxide and water on white-coat samples _... _ 364

5. Volume changes

6. Recommendations relating to prevention of efflorescence on plaster _........... 364

III. Magnesium sulfate efflorescence on cement products

IV. Summary _...

V. References

\section{INTRODUCTION}

Efflorescence is defined as the deposit of crystalline salts on the surface of masonry or plaster. These salts are usually present in the interior of the masonry or plaster and are dissolved by water and transported to the surface, and there redeposited by evaporation of the water, with consequent recrystallization of the salts. For efflorescence to occur, there must be both soluble salts and water to dissolve and transfer the salts. Efflorescence is frequently associated with and may be the cause of disintegration of the surface of plaster.

One type of efflorescence occurring on plaster consists chiefly of magnesium sulfate, which is not a constituent of the plaster. In order to determine the origin of the salt, some experiments were performed on the individual constituents and mixtures having the composition of white-coat plaster. The results are given in the report.

$519080-43-2$ 


\section{EFFLORESCENCE ON PLASTER}

\section{CHEMICAL CONSTITUENTS OF PLASTER AND EFFLORESCENCE}

Plaster ordinarily consists of a base coat of gypsum and sand and a finish coat of gypsum and hydrated lime. The hydrated lime may be either a high-calcium or a dolomitic type, the latter being used in a majority of the finish-coat plasters. The principal chemical constituents of set plaster (aside from the sand, which has a very low solubility in water) are $\mathrm{CaSO}_{4} \cdot 2 \mathrm{H}_{2} \mathrm{O}, \mathrm{Ca}(\mathrm{OH})_{2}, \mathrm{MgO}$, and $\mathrm{Mg}(\mathrm{OH})_{2}$.

The $\mathrm{Ca}(\mathrm{OH})_{2}$ combines with $\mathrm{CO}_{2}$ from the air to form $\mathrm{CaCO}_{3}$, the reaction proceeding slowly in normally dry plaster but more rapidly when the optimum amount of moisture is present. The extent of carbonation of the hydrated lime varies greatly and frequently is unrelated to the age of the plaster, as shown by the analyses of many plasters. For example, samples from some buildings 30 years old contained about equal quantities of $\mathrm{CaCO}_{3}$ and $\mathrm{Ca}(\mathrm{OH})_{2}$, whereas all or nearly all of the $\mathrm{Ca}(\mathrm{OH})_{2}$ was converted to $\mathrm{CaCO}_{3}$ in other samples from buildings much less than 30 years old. Regions may exist anywhere in plaster, but especially at the surface, where $\mathrm{Ca}(\mathrm{OH})_{2}$ has been completely carbonated.

The composition of a sample of efflorescence on plaster, computed from an analysis, was as follows:

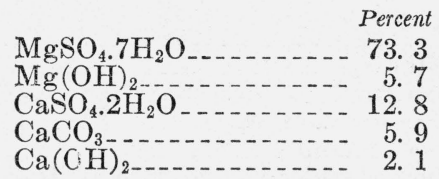

\section{FORMATION OF NESQUEHONITE}

Complete conversion of $\mathrm{Ca}(\mathrm{OH})_{2}$ to $\mathrm{CaCO}_{3}$ had not occurred in the majority of plasters analyzed. In a few samples, however, the amounts of $\mathrm{CO}_{2}$ found were enough to carbonate the total contents of $\mathrm{Ca}(\mathrm{OH})_{2}$ and $\mathrm{MgO}$. Furthermore, some samples contained $\mathrm{MgO}$, $\mathrm{CO}_{2}$, and chemically combined water in the molar ratios corresponding to those of the mineral nesquehonite, $\mathrm{MgCO}_{3} \cdot 3 \mathrm{H}_{2} \mathrm{O}$. The chemical evidence (by W. F. Clarke, of this Bureau) for the existence of this compound in plaster was confirmed by microscopical and X-ray analyses.

Johnston [1] ${ }^{1}$ and Kline [2], respectively, showed that $\mathrm{MgCO}_{3} \cdot 3 \mathrm{H}_{2} \mathrm{O}$ in water remains the stable phase, at $16^{\circ}$ and $25^{\circ} \mathrm{C}$, as long as the air in contact with the water contains at least 0.04 percent of $\mathrm{CO}_{2}$. They found that when the concentration of $\mathrm{CO}_{2}$ was less than 0.04 percent, the $\mathrm{MgCO}_{3} \cdot 3 \mathrm{H}_{2} \mathrm{O}$ changed very slowly to $\mathrm{Mg}(\mathrm{OH})_{2}$. Johnston indicated that at higher temperatures $\mathrm{MgCO}_{3} \cdot 3 \mathrm{H}_{2} \mathrm{O}$ would be the stable phase only at higher concentrations of $\mathrm{CO}_{2}$. While the $\mathrm{CO}_{2}$ content of the outside air is ordinarily about 0.04 percent, that of the air inside of buildings is variable and often much greater. The concentration may reach 0.1 percent or more, well above that at which $\mathrm{MgCO}_{3} \cdot \mathrm{H}_{2} \mathrm{O}$ is stable.

\footnotetext{
1 Figures in brackets indicate the literature references at the end of this paper.
} 


\section{REACTION OF NESQUEHONITE WITH GYPSUM}

Some information regarding the possibility that nesquehonite, gypsum, and lime react in moist plaster may be obtained from the respective solubilities of these compounds given in table 1 .

TABLE 1.-Solubilities of some compounds occurring or formed in plaster

\begin{tabular}{|c|c|c|c|c|}
\hline Compound & \multicolumn{2}{|c|}{ Solubitity } & Temperature & Reference \\
\hline $\begin{array}{l}\mathrm{CaSO} \mathrm{O}_{4} \cdot 2 \mathrm{H}_{2} \mathrm{O} \\
\mathrm{Ca}(\mathrm{OH})_{2} \\
\mathrm{MgCO} \cdot 3 \mathrm{H}_{2} \mathrm{O} \\
\mathrm{Mg}(\mathrm{OH})_{2} \\
\mathrm{CaCO}_{3}\end{array}$ & $\begin{array}{l}\mathrm{g} / \mathrm{kg} \\
2.082 \\
1.464 \\
1,874 \\
0.027 \\
.066\end{array}$ & $\begin{array}{c}g \text { mole/ } \mathrm{kg} \\
121 \times 10^{-4} \\
198 \\
136 \\
\quad 4.6 \\
6.6\end{array}$ & $\begin{array}{l}{ }^{\circ} C \\
25 \\
25 \\
25 \\
25 \\
16\end{array}$ & $\begin{array}{l}{[3]} \\
{[4]} \\
{[2]} \\
{[5]} \\
{[1]}\end{array}$ \\
\hline
\end{tabular}

The solubility relations of $\mathrm{CaSO}_{4} \cdot 2 \mathrm{H}_{2} \mathrm{O}$ and $\mathrm{MgCO}_{3} \cdot \mathrm{H}_{2} \mathrm{O}$ are such that the following reaction will proceed toward the right, since $\mathrm{CaCO}_{3}$ is relatively insoluble: ${ }^{2}$

$$
\mathrm{CaSO}_{4} \cdot 2 \mathrm{H}_{2} \mathrm{O}+\mathrm{MgCO}_{3} \cdot 3 \mathrm{H}_{2} \mathrm{O}+2 \mathrm{H}_{2} \mathrm{O} \rightleftharpoons \mathrm{CaCO}_{3}+\mathrm{MgSO}_{4} \cdot 7 \mathrm{H}_{2} \mathrm{O} \text {. }
$$

The other product of this reaction, $\mathrm{MgSO}_{4} \cdot 7 \mathrm{H}_{2} \mathrm{O}$, is the chief constituent of efflorescence on plaster.

Tests were made to determine whether or not the reaction products indicated by equation 1 could be produced when a water suspension of $\mathrm{MgO}$ and $\mathrm{CaSO}_{4} \cdot 2 \mathrm{H}_{2} \mathrm{O}$ was exposed to $\mathrm{CO}_{2}$ from the air. After several days small crystals were observed at the surface of the solution. These crystals were shown to be $\mathrm{CaCO}_{3}$ by microscopical analysis. The reaction proceeded slowly, and at 7 months, chemical analysis of the sediment indicated that nearly all the $\mathrm{MgO}$ had been changed to $\mathrm{MgSO}_{4} \cdot 7 \mathrm{H}_{2} \mathrm{O}$. In another test $\mathrm{MgSO}_{4} \cdot 7 \mathrm{H}_{2} \mathrm{O}$ was produced in a few hours by bubbling $\mathrm{CO}_{2}$ through a suspension of $\mathrm{MgO}$ and $\mathrm{CaSO}_{4} \cdot 2 \mathrm{H}_{2} \mathrm{O}$. It was formed also when air was bubbled through a similar suspension, the experiment being conducted at $30^{\circ} \mathrm{C}$ near an open window in a large laboratory $(30 \times 45 \times 12 \mathrm{ft})$ with all gas burners shut off. The $\mathrm{CO}_{2}$ concentration of the air used in this test was probably near that of the outside air. It would appear therefore that $\mathrm{MgSO}_{4} \cdot 7 \mathrm{H}_{2} \mathrm{O}$ could be formed in plaster by the action of $\mathrm{CO}_{2}$ and water on the constituents gypsum and hydrated dolomitic lime.

While these reactions take place readily in solution, ideal conditions seldom exist for rapid reaction in ordinary plaster for two reasons. First, adequate amounts of water often are not present. Second, $\mathrm{MgCO}_{3} \cdot 3 \mathrm{H}_{2} \mathrm{O}$ can not be formed in contact with $\mathrm{Ca}(\mathrm{OH})_{2}$ because they react, yielding insoluble $\mathrm{Mg}(\mathrm{OH})_{2}$ and $\mathrm{CaCO}_{3}$. This explains why $\mathrm{MgCO}_{3} \cdot 3 \mathrm{H}_{2} \mathrm{O}$ is so rarely found in ordinary plaster.

Since $\mathrm{MgCO}_{3} \cdot 3 \mathrm{H}_{2} \mathrm{O}$ is the intermediate product in the production of $\mathrm{MgSO}_{4} .7 \mathrm{H}_{2} \mathrm{O}, \mathrm{Ca}(\mathrm{OH})_{2}$ must be changed to $\mathrm{CaCO}_{3}$ before $\mathrm{MgSO}_{4}$. $7 \mathrm{H}_{2} \mathrm{O}$ also can be produced.

Obviously, equilibrium is seldom established throughout a plaster, and in obtaining a sample of efflorescence it is difficult sometimes to keep from contaminating the efflorescence with compounds that would not be present if equilibrium had been established. This accounts for the presence of $\mathrm{Ca}(\mathrm{OH})_{2}$ in the analysis of the efflorescence sample previously given.

${ }^{2}$ Hydrates are indicated in the equation "to"avoid the impression that anhydrite and magnesite occur in plaster. 


\section{EFFECT OF CARBON DIOXIDE AND WATER ON WHITE-COAT SAMPLES}

Having demonstrated that $\mathrm{MgO}$ and $\mathrm{CaSO}_{4} \cdot 2 \mathrm{H}_{2} \mathrm{O}$, in a water suspension, can react with $\mathrm{CO}_{2}$ to form $\mathrm{MgSO}_{4}$, an attempt was made to produce efflorescence on specimens of white-coat plaster. Prisms having the composition of white-coat plaster were prepared from 2 parts by weight of dolomitic hydrated lime and 1 part of calcined gypsum. Similar prisms were prepared from a high-calcium hydrated lime and calcined gypsum. These specimens were then subjected to moisture and $\mathrm{CO}_{2}$ by storing them in a closed cylinder over but not in contact with water and introducing $\mathrm{CO}_{2}$ from a cylinder of compressed $\mathrm{CO}_{2}$ gas until a pressure of 50 pounds per square inch was attained. The specimens were kept in the cylinder for a day and were then removed and allowed to dry in the laboratory. After 10 cycles of alternate treatments with moist $\mathrm{CO}_{2}$ and dry air, a profuse efflorescence similar in appearance and composition to that found on plaster had developed in the specimens prepared with the dolomitic hydrated lime (fig. 1, specimens 440 to 447). No efflorescence, however, appeared on the identically treated specimens (457 to 459) containing highcalcium hydrated lime.

Although efflorescence did not appear on the white-coat samples composed of a high-calcium lime and gypsum, it cannot be concluded that trouble other than efflorescence may not ensue when high-calcium limes are used, for it is a well-known fact that ultimately the continual presence of moisture is detrimental to almost any type of plaster.

\section{VOLUME CHANGES}

The disintegration of the white coat during efflorescence is not surprising if consideration is given to the large increase in volume accompanying the conversion of the plaster constituent $\mathrm{MgO}$ to $\mathrm{MgSO}_{4} .7 \mathrm{H}_{2} \mathrm{O}$. The following computed net volume increases, occurring with the production of the various magnesium compounds in the process, were obtained from the data in table $2: \mathrm{MgO}$ to $\mathrm{Mg}(\mathrm{OH})_{2}$. 124 percent; $\mathrm{MgO}$ to $\mathrm{MgCO}_{3} \cdot 3 \mathrm{H}_{2} \mathrm{O}, 585$ percent; and $\mathrm{MgO}$ to $\mathrm{MgSO}_{4}$. $7 \mathrm{H}_{2} \mathrm{O}, 1,280$ percent. Such large increases in volume account for the disintegration of the plaster, even though the change of $\mathrm{MgO}$ to $\mathrm{MgSO}_{4} .7 \mathrm{H}_{2} \mathrm{O}$ may be incomplete.

TABLE 2.-Molecular volumes of some compounds found in plaster and efforescence

\begin{tabular}{|c|c|c|c|}
\hline Compound & $\begin{array}{c}\text { Molecular } \\
\text { weight }\end{array}$ & Density & $\begin{array}{c}\text { Molecular } \\
\text { volume }\end{array}$ \\
\hline $\begin{array}{l}\mathrm{MgO} \\
\mathrm{Mg}(\mathrm{OH})_{2} \\
\mathrm{MgCO}_{3} 3 \mathrm{H}_{2} \mathrm{O} \\
\mathrm{MgSOO}_{4} \\
\mathrm{MgSO}_{4} .7 \mathrm{H}_{2} \mathrm{O}\end{array}$ & $\begin{array}{r}40.32 \\
58.34 \\
138.38 \\
120.38 \\
246.49\end{array}$ & $\begin{array}{l}g / m l \\
3.7 \\
2.38 \\
1.85 \\
2.66 \\
1.64\end{array}$ & $\begin{array}{l}m l \\
10.9 \\
24.4 \\
74.8 \\
46.5 \\
150.2\end{array}$ \\
\hline
\end{tabular}

\section{RECOMMENDATIONS RELATING TO PREVENTION OF EFFLORESCENCE ON PLASTER}

Moisture is essential for the formation of efflorescence on plaster. Even though efflorescence may not appear, moisture is very detri- 


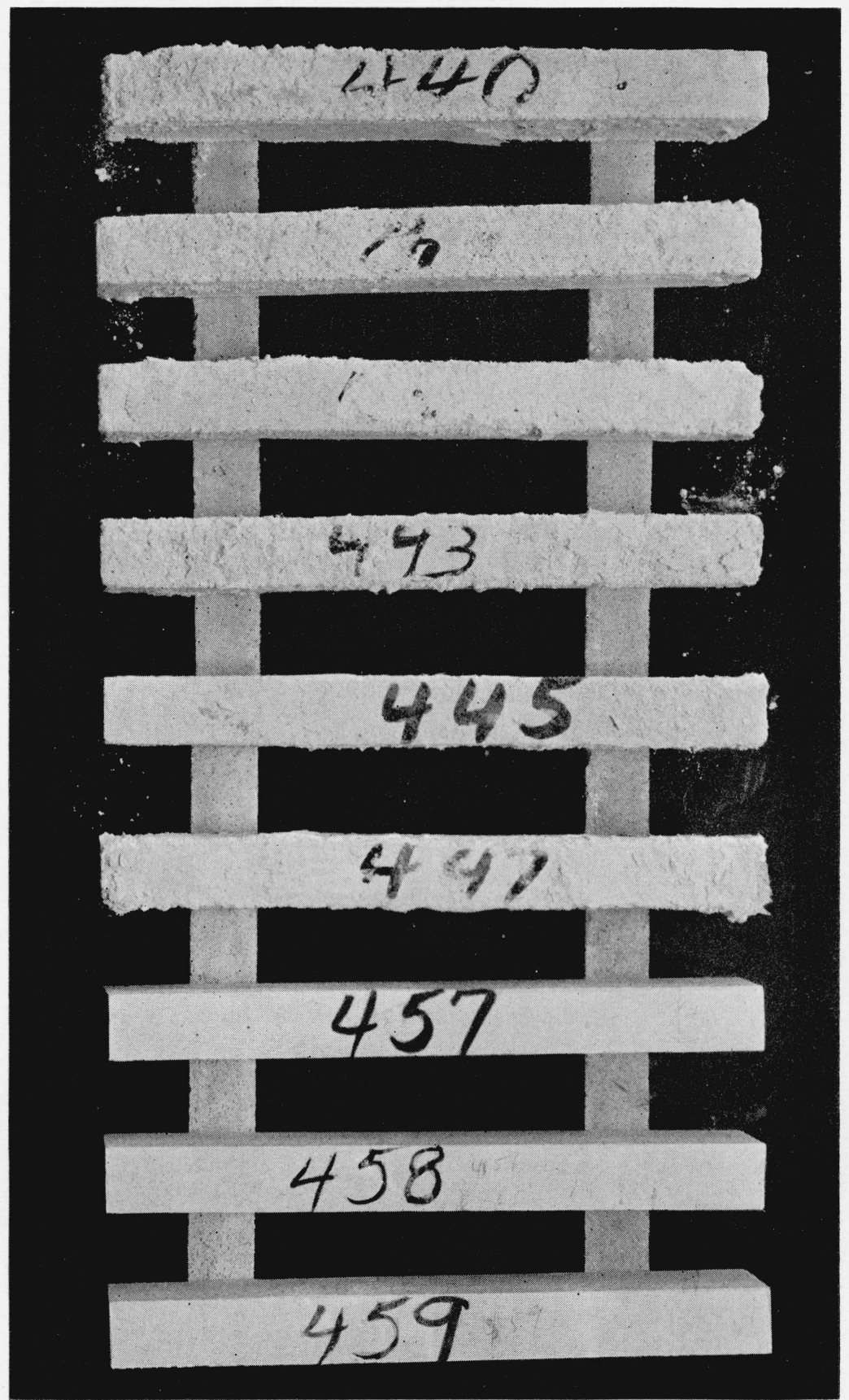

FIGURE 1.-Efflorescence produced experimentally by the action of water and carbon dioxide on plaster samples. 
mental to any plaster and leads to the disintegration of the plaster and to rotting of adjacent wood. In general, adequate protection from moisture over the greater portions of plaster has been considered in the design of buildings. Unfortunately, faulty design has resulted in certain areas of plaster becoming repeatedly moist. In such instances efflorescence appears. Plaster applied directly to outside masonry walls may become damp because of condensation of moisture. Furred walls should eliminate this source of trouble. The furring not only tends to keep the temperature of the plaster above the dew point but also diminishes the transfer of water from leaking walls to the plaster. Ventilation of insulated walls furnishes a means of escape for water accumulating in the cold insulation. Insulation containing moisture in contact with plaster produces conditions favoring the formation of $\mathrm{MgCO}_{3} \cdot 3 \mathrm{H}_{2} \mathrm{O}$ and $\mathrm{MgSO}_{4} \cdot 7 \mathrm{H}_{2} \mathrm{O}$. Unless cold-water pipes passing through plastered walls are provided with sleeves, the condensed moisture may collect in the adjacent plaster and produce effiorescence.

\section{MAGNESIUM SULFATE EFFLORESCENCE ON CEMENT PRODUCTS}

Magnesium sulfate efflorescence has been observed also on cement mortar, cinder block, and other cement products. Since $\mathrm{CaSO}_{4}$ and $\mathrm{MgO}$ are among the constituents of cement, it is possible that they may react in the prescence of $\mathrm{CO}_{2}$ and moisture to form $\mathrm{MgSO}_{4}$.

In order to determine the combined action of $\mathrm{CO}_{2}$ and water in extracting $\mathrm{MgO}$ and $\mathrm{SO}_{3}$ from a cement, $\mathrm{CO}_{2}$ was bubbled through a water suspension of a cement and the solid phase analyzed. In 3 days the $\mathrm{MgO}$ content of the solid phase was reduced from 4.7 to 2.0 percent and the $\mathrm{SO}_{3}$ content from 1.8 to 0.6 percent.

Tricalcium sulfoaluminate, $3 \mathrm{CaO} . \mathrm{Al}_{2} \mathrm{O}_{3} \cdot 3 \mathrm{CaSO}_{4} \cdot 31 \mathrm{H}_{2} \mathrm{O}$, formed during the setting of cement contains $\mathrm{CaSO}_{4}$ but is a much less soluble compound than gypsum, $\mathrm{CaSO}_{4} \cdot 2 \mathrm{H}_{2} \mathrm{O}$. In experiments to determine if sulfate could be extracted from tricalcium sulfoaluminate, $\mathrm{CO}_{2}$ was passed through a water suspension of this compound and the solids were examined microscopically. After a short time, the precipitation of $\mathrm{Al}(\mathrm{OH})_{3}$ and $\mathrm{CaCO}_{3}$ indicated the decomposition of tricalcium sulfoaluminate had made available $\mathrm{CaSO}_{4}$ for reaction with $\mathrm{MgCO}_{3}$ $3 \mathrm{H}_{2} \mathrm{O}$. It was found also that the sulfoaluminate could be decomposed by bubbling air of normal $\mathrm{CO}_{2}$ concentration through the suspension. It would appear, therefore, that $\mathrm{MgSO}_{4}$ efflorescence might arise also from the reaction of $\mathrm{CO}_{2}$ and water with the magnesia and sulfatebearing compounds in cement.

No attempt was made to produce efflorescence on cement experimentally. However, some interesting information was obtained from an investigation conducted by Rogers and Blaine [6], who reported on the efflorescence on mortars prepared from 41 commercial masonry cements. Their mortar specimens were immersed in water for 72 hours in order to determine the absorption. Such treatment would be expected to remove much of the readily soluble salts. The specimens were then placed on end in a tray of water to a depth of one-half inch. Observations for efflorescence at the end of 3 months were reported. The composition of the efflorescence was not determined. It is interest. ing to note that their mortars showing no efflorescence had an average 
$\mathrm{MgO}$ content of 5.0 percent, those with slight efflorescence 8.8 percent, and those showing pronounced efflorescence 19.7 percent. $^{3}$

The amount of $\mathrm{MgSO}_{4} .7 \mathrm{H}_{2} \mathrm{O}$ formed in cement products would be limited by the amount of sulfate or magnesia present. Magnesia might be extracted also by water and $\mathrm{CO}_{2}$ from magnesium carbonate in the sand or aggregate. Magnesium chloride also might be formed from reaction of $\mathrm{CaCl}_{2}$ with $\mathrm{MgCO}_{3} \cdot 3 \mathrm{H}_{2} \mathrm{O}$.

\section{SUMMARY}

Hydrated magnesium sulfate was identified as the principal constituent of efflorescence on plaster. Its formation was accounted for by reactions involving magnesia and gypsum in the plaster, $\mathrm{CO}_{2}$ from the air, and moisture. This type of efflorescence was observed also on some cement products.

Magnesium sulfate was produced experimentally by the action of $\mathrm{CO}_{2}$ on a water suspension of $\mathrm{MgO}$ and $\mathrm{CaSO}_{4} \cdot 2 \mathrm{H}_{2} \mathrm{O}$.

Hydrated magnesium sulfate efflorescence was formed on whitecoat plaster specimens containing dolomitic hydrated lime and gypsum when treated with moist $\mathrm{CO}_{2}$ and then allowed to dry. The disintegration accompanying the efflorescence was explained by the large volume changes involved in the formation and crystallization of $\mathrm{MgCO}_{3} \cdot 3 \mathrm{H}_{2} \mathrm{O}$ and $\mathrm{MgSO}_{4} .7 \mathrm{H}_{2} \mathrm{O}$.

If plaster is kept dry, no trouble with efflorescence is experienced, because moisture is necessary to transfer the salts to the surface and to take part in the reaction. Plaster, therefore, should be protected from moisture by keeping it above the dew point. Moisture accumulations from various sources, such as transmission through pervious walls and leaks from water and steam pipes, should be prevented.

Magnesium sulfate also is found as efflorescence on concrete, possibly being derived from $\mathrm{MgO}$ and sulfate in the cement by reaction with $\mathrm{CO}_{2}$ and water. The compound $3 \mathrm{CaO} \cdot \mathrm{Al}_{2} \mathrm{O}_{3} \cdot 3 \mathrm{CaSO}_{4}$. $.31 \mathrm{H}_{2} \mathrm{O}$, a constituent of set cement is decomposed by $\mathrm{CO}_{2}$ and water, making the $\mathrm{CaSO}_{4}$ available for reaction with $\mathrm{MgCO}_{3} \cdot 3 \mathrm{H}_{2} \mathrm{O}$ to form soluble $\mathrm{MgSO}_{4}$.

The author is indebted to W. F. Clarke for the chemical evidence and to H. F. McMurdie for the X-ray evidence that nesquehonite occurs in plaster.

\section{REFERENCES}

[1] John Johnston, J. Amer. Chem. Soc. 3\%, 2001 (1915).

[2] Walter D. Kline, J. Amer. Chem. Soc. 51, 2093 (1929).

[3] J. A. Hulett and L. E. Allen, J. Amer. Chem. Soc. 24, 667 (1902).

[4] J. Johnston and C. Grove, J. Amer. Chem. Soc. 53, 3976 (1931).

[5] L. Whitby, Trans. Faraday Soc. 29, 1318 (1933).

[6] J. S. Rogers and R. L. Blaine, J. Research NBS 13, 811 (1934) RP746.

\section{Washington, February 5, 1943.}

3 The chemical analyses for cements 38 and 39 are interchanged in table 1 of reference [6]. $\mathrm{Also}$, the $\mathrm{SO}_{3}$ reported for their sample 1 appears to have been determined on a sample that had been ignited with a blast lamp, which would result in the loss of $\mathrm{SO}_{3}$ and alkalies. Redetermination of $\mathrm{SO}_{3}$ on a sample not ignited gave 2.6 percent. 